\title{
On the Impact of Globalization on Financial Development: A Multi-country Panel Study
}

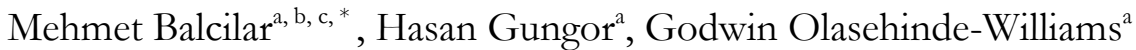

\begin{abstract}
In this paper, we examine whether globalization effects financial development by generating incentives for institutional reforms, and therefore, enhance economic growth due to increased financial development in addition other channels. Specifically, we examine the relationship between globalization and financial development for a panel data of 36 countries over the period 1996-2016, using panel data estimation methods. In addition to overall globalization, we also consider economic, political and social subdimensions of globalization. Moreover, not only the financial institutional development but also its access, depth and efficiency dimensions are considered. The study also controls for several other covariates affecting financial development. The shows that all measures of globalization strongly enhances financial institutional development and its subdimensions except the efficiency for which the evidence is weaker. Thus, globalization has generated incentives for institutional reforms, and therefore contributed positively to financial institutional development and economic growth.
\end{abstract}

Keywords: Globalization, Financial Development, Panel Data

\section{Introduction}

Globalization and its impacts on the economy have been one of the main concern of the scholarly researchers over the last three decades. Vast amount of research shed light on the various aspects of globalization and its impact on various sectors and the overall performance of the economies. The literature has generally emphasized that the link between financial development and the globalization has become stronger over the three decades as globalization stimulated institutional reforms that promote financial development economic growth. Thus, in additional to its growth enhancing effect through trade, globalization might further enhance economic growth indirectly via its effect on financial development (Mishkin, 2009). This has made the policy makers to reconsider their policies in order to use advantages and increase the economic gains from the benefits of the globalization with the ultimate goal of sustainable growth. Globalization provides several important benefits for those economies who are getting more integrated into the global economic system. First, it helps for the development of financial sector. Second, it facilitates technology and knowhow transfer from developed economies to developing economies. Third, it provides lower cost of capital for the domestic economy via capital mobility. Fourth, it helps for the accumulation of savings domestically. Fifth, it provides access to those markets that requires improved

\footnotetext{
a Eastern Mediterranean University, Northern Cyprus, via Mersin 10, Turkey.

b Montpellier Business School, Montpellier, France

c University of Pretoria, Pretoria, 0002, South Africa

* Corresponding author. E-mail: mehmet@mbalcilar.net.
} 
specialization in production. Sixth, it enables improvements in macroeconomic policies and institutions via higher competitive pressures from global world. ${ }^{1}$ The first through fourth effects are known as direct channels through which globalization enhances economic growth. The last two are the indirect channels (Prasad et al., 2003; Schmukler and Abraham, 2017).

However, globalization is not free from the risks that can destabilize financial markets and eventually slow down the economic growth. In some cases, high degree of global integration may pose risks that are not directly originating from the domestic economy but transmitted from another economies as it was in the case of 2007 - 2009 global financial crises. This was the result of global risk sharing in global financial markets. Thus, the nexus between globalization and its impacts on the domestic economies in general and financial markets in particular is an temporally question that should be examined empirically.

Financial development have also received great attention both from academic and policy circles. By definition, financial development refers to better mobilization of savings in the form of accumulated liquid assets, acquiring information about investments and allocation of resources, exercising corporate control by monitoring the managers, facilitation of risk management and facilitation of trade and contracts (Levine, 1997). The initial studies were mainly focused on the possible links between financial development and growth both theoretically and empirically. The main research question was whether financial development had any leading role on economic growth and vice versa. Furthermore, some studies also attempted to identify the possible channels through which financial development effects growth. The findings until now can be best described as mixed. Ang (2008), Beck (2011) and Paşalı (2013) present an extensive survey of the substantial amount of research findings on the topic.

Given the importance of globalization for integrating a country to global economic system and the role of financial development on the growth, it is important to investigate the possible effect of globalization on financial development. In other words, there may be channels through which globalization effects financial development. Mishkin (2009) argues that institutions are important establishments in achieving successful financial development. That is, financial markets cannot perform their functions well without having well established institutions which is essential for economic growth. But this is not an easy task to achieve since it takes time, energy and resources to build sound institutions that can adapt to local conditions. Furthermore, interest group theory of financial development proposed by Rajan and Zingales (2003) argues that local incumbents usually oppose the necessary reforms to build up sound institutions. Thus, it becomes even more difficult for emerging economies to successfully implement reforms that will help to construct a well-functioning financial system, which will contribute to the economic growth. Mishkin (2009) further argues that there is no standard recipe on the exact mix of institutional characteristics that best promotes financial development and thus economic growth. However, the factors that must be in recipe are strong

1 Prasad et al. (2003) states that improvements in macroeconomic policies and institutions via higher competitive pressures from global world can also be called the "discipline effect". 
property rights, a legal system that enforces contracts quickly and fairly, elimination of corruption, high quality of financial reporting and information, good corporate governance, and sound prudential supervision and regulation of the banking system. Therefore, he argues in the same lines as Prasad et al. (2013), i.e., globalization, by the discipline effect, improves institutions with a given mix, so that it helps financial development to further improve and thus contribute to the economic growth.

This study examines the impact of globalization on financial institutions development in a panel of thirty-six countries. Through this study, we attempt to provide empirical evidence for the Mishkin (2009) hypothesis using up-to-date panel data estimation techniques. Our study differs from previous studies in the following three ways. First, this study is the first to consider the various dimensions of financial development (access, depth and efficiency) while testing the Mishkin (2009) hypothesis. Second, because globalization is a multifaceted concept with economic, political and social dimensions, our study accounts for all these three dimensions. Third, we adopt a panel framework that is robust to challenges posed by cross-sectional dependency and countryspecific heterogeneity.

The rest of the paper is organizedd as follows: Section 2 provides a review of the relevant literature. Section 3 presents the data, empirical model and econometric methods followed, Section 4, which presents the empirical findings. Finally, Section 5 concludes.

\section{Empirical Literature Review}

There are limited amount of empirical research on the Mishkin (2009) hypothesis. Law and Azman-Saini (2012) using banking sector and stock market development indicators examined the effect of institutional quality on financial development in developed and developing countries. Their findings support the idea that high quality institutional environment is important in explaining financial development. By using dynamic panel system generalized method of moment (GMM) estimation, they showed that the banking sector and the stock market respond differently to institutions and governance. Law et al. (2014) analyzing the East Asian case, found that globalization has a significant causal influence on institutional quality, and institutional reforms have in turn facilitated and supported financial development in particular of the banking sector. Furthermore, their findings reveal that globalization has a favorable causal impact on stock market but without going through the institutional quality channel.

Falahaty and Law (2012) studying nine Middle East and North Africa (MENA) region countries found evidence that although globalization effects financial development and economic growth positively, it does not play any role in institutional reforms that promotes financial development and growth. Likewise, Tovar Garcia (2012) studied the impact of financial globalization on the development of the financial sector in transition economies by employing a dynamic panel data model. His findings also give support to the idea that domestic economies fail to receive available benefits from globalization unless there is macroeconomic and political stability, low level or no corruption, well established legal system and institutional development, and strong supervisory agencies and skills. Muye and Muye (2017) examined the causality between globalization, financial development and institutional development for three economic blocks as BRICS, MINT 
and ECOWAS. Their findings show strong evidence that globalization has a causal effect on institutions and in turn institutions cause financial development in banking sector. In stock market, globalization still cause development but not through institutional channel. Kandil et al. (2015) also studied the 32 developed and developing economies and found some contradictory results to that of Law and Azman-Saini (2012) with a smaller sample of countries and with a different methodology. Their findings reveal that financial development effects economic growth and globalization positively, whereas globalization does not support financial development. Furthermore, quality of institutions do not impact financial development but financial development does effect quality of institutions positively.

\section{Data, Model and Econometric Methods 3.1. Data}

To determine the impact of globalization on financial development, the study uses annual data from 36 countries covering the period 1996-2016. The list of countries included in our study is provided in the appendix. The choice of the period of study is related to the availability of data on the variables of interest. The dependent variable, financial institution development, is measured by the financial institution development index computed by the International Monetary Fund (IMF). ${ }^{2}$ The dataset contains three indices that summarize how developed financial institutions are in terms of their depth, access, and efficiency. The three indices are further aggregated into a single, overall index of financial institution development. The independent variable of main interestglobalization - is proxied by the globalization index from Swiss Economic Institute's KOF database (Konjunkturforschungs-stelle). The index was proposed by Dreher (2006) and updated by Gygli et al. (2018). It is a composite index scaled between 0 (not globalized) and 100 (highly globalized) which measures globalization along economic, social and political dimensions.

We also include a set of control variables that are commonly regarded as key determinants of financial development-institutional quality, macroeconomic policies and income. Porta et al. (1997, 1998), Acemoglu et al. (2001), Mayer and Sussman (2001), and Beck et al. (2003) are some of the popular studies emphasizing the importance of institutions for financial development. We therefore include a measure for institutional quality by averaging the six dimensions of governance provided in the World Bank's Worldwide Governance Indicators (WGI): voice and accountability, political stability and absence of violence, government effectiveness, regulatory quality, rule of law, and control of corruption. By averaging the six dimensions, we are able to address possible issues of multicolinearity as all the dimensions appear to measure the same broad concept (Langbein and Knack, 2010). Several other researchers have similarly adopted the same approach to obtain a single, broader index (e.g. Easterly, 2002; Al-Marhubi, 2004; Bjørnskov, 2006; Le et al., 2016). The importance of macroeconomic policies such as openness of goods markets and financial liberalization in promoting financial development has also been confirmed by various studies (Shaw, 1973; Do and

2 The data is accessible at http://data.imf.org/?sk=388DFA60-1D26-4ADE-B505A05A558D9A42\&sId=1479329132326. 
Levchenko, 2004; McKinnon, 2010; Huang, 2011). We therefore include trade openness and financial openness as regressors. Also, the importance of income levels for financial development has been well documented by Levine (1999, 2003, 2005). We thus also include gross domestic product per-capita as one of the regressors. Data on trade openness and gross domestic product per-capita is obtained from World Development Indicators (WDI). ${ }^{3}$ Financial openness data is sourced from Chinn-Ito financial openness index. ${ }^{4}$

\subsection{Model}

Our study applies panel data analysis to examine the impact of globalization on financial development. Four basic regression models are specified, the first one, which is the main model, estimates the impact of globalization (economic, political, social and overall) on the overall financial institution development index. The other three models estimate the effect of globalization (economic, political, social and overall) on the subindices of the overall financial institution development index (indices for financial institution access, depth and efficiency). The model is presented below:

$$
{ }_{\varepsilon_{i t}}^{F I D M_{i t}^{g}}=\alpha_{0 i}+\alpha_{1 i} G L O B_{i t}^{h}+\alpha_{2 i} G D P P C_{i t}+\alpha_{3 i} I Q_{i t}+\alpha_{4 i} T O_{i t}+\alpha_{5 i} F O_{i t}+
$$

where $i$ denotes country, $t$ denotes year, $F I D M_{i t}^{g}$ is a measure of financial institutional development with $g=F I I, F I A, F I D, F I E$, where $F I I$ is financial institution development in country, FIA is financial institution access in country, FID is financial institution depth in country, and FIE is financial institution efficiency. $G L O B_{i t}^{h}$ represents globalization-economic (egi), political (pgi), social (sgi) and overall (ogi) with $h=$ egi,pgi,sgi,ogi - in country $i$ at time $t$ respectively. GDPPC $C_{i t}$ stands for gross domestic product per capita in country $i$ at time $t$. IQ refers to institutional quality, TO means trade openness, $F O$ is financial openness. $\alpha$ represents the vector of coefficients and $\varepsilon$ represents the idiosyncratic error term. All variables are used in their logarithmic forms.

\subsection{Econometric method}

\subsubsection{Panel unit-root tests with cross-sectional dependence and heterogeneous slopes}

An important concern arises in panel data estimations. This concern is the likelihood that countries within the panel are interdependent due to high level of financial and economic integration between them. Shocks emanating from one country can be transmitted to the other countries. Not controlling for the effect of this issue can lead to misleading inferences. We thus start by testing for cross-sectional dependency and country-specific heterogeneity. We first apply the following cross-sectional dependence (CD) tests;

\footnotetext{
${ }^{3}$ WDI data is obtained from http://databank.worldbank.org/data/reports.aspx? source $=$ worlddevelopment-indicators.

${ }^{4}$ Chinn-Ito financial openness index is available at http://web.pdx.edu/ ito/Chinn-Ito website.htm.
} 
Breusch-Pagan (1980) LM test, Pesaran (2004) Scaled LM test, Pesaran (2004) CD test and Pesaran et al. (2008) Bias-adjusted LM test. The test statistics for the four cases are given respectively as:

$$
L M=\sum_{i=1}^{N-1} \sum_{j=i+1}^{N} T_{i j} \hat{p}_{i j}^{2} \rightarrow \chi^{2} \frac{N(N-1)}{2}
$$

$$
L M_{S}=\sqrt{\frac{1}{N(N-1)}} \sum_{i=1}^{N-1} \sum_{j=i+1}^{N}\left(T_{i j} \hat{p}_{i j}^{2}-1\right) \rightarrow N(0,1)
$$

$$
\begin{aligned}
& C D_{p}=\sqrt{\frac{2}{N(N-1)}} \sum_{i=1}^{N-1} \sum_{j=i+1}^{N} T_{i j} \hat{p}_{i j} \rightarrow N(0,1) \\
& L M_{A D J}=\sqrt{\frac{1}{N(N-1)}} \sum_{i=1}^{N-1} \sum_{j=i+1}^{N}\left(T_{i j} \hat{p}_{i j}^{2}-1\right)-\frac{N}{2(T-1)} \rightarrow N(0,1)
\end{aligned}
$$

In all cases, the null of no cross-sectional dependence is represented as: $H_{0}: p_{i j}=$ $\operatorname{corr}\left(\mu_{i t}, \mu_{j t}\right)=0$ for $i \neq j$ and $\hat{p}_{i j}^{2}$ represents the correlation coefficients from residuals.

Next, we apply the Pesaran and Yamagata (2008) standardized version of the Swamy (1970) homogeneity test (delta tests). Under the null of slope homogeneity, the Swamy (1970) test is first modified thus:

$$
\tilde{S}=\sum_{i=1}^{N}\left(\hat{\beta}_{i}-\hat{\beta}_{W F E}\right)^{\prime} X_{I}^{\prime} \frac{M_{\tau} X_{i}}{\widetilde{\sigma}_{i}^{2}}\left(\hat{\beta}_{i}-\hat{\beta}_{W F E}\right)
$$

where $\hat{\beta}_{i}=$ Pooled OLS estimator, $\hat{\beta}_{W F E}=$ weighted fixed effect pooled estimator and $\tilde{\sigma}_{i}^{2}$ is the estimator.

Then the standard dispersion statistics is calculated as:

$\tilde{\Delta}=\sqrt{N}\left(\frac{N^{-1} \tilde{S}-k}{2 k}\right)$

Alternatively, the bias adjusted version of the standard dispersion statistics is also calculated thus:

$$
\tilde{\Delta}_{A d j}=\sqrt{N}\left(\frac{N^{-1} \tilde{S}-E\left(\tilde{z}_{i t}\right)}{\sqrt{\operatorname{var}\left(\tilde{z}_{i t}\right)}}\right)
$$

Finally, we adopt the cross-sectionally augmented IPS (Im et al., 2003) panel unit root tests of Pesaran (2007). This unit root test developed by Pesaran (2007) accommodates cross-sectional dependence and heterogeneity. Pesaran (2007) extends the standard Dickey Fuller/augmented Dickey Fuller regressions with the cross-section averages of the lagged levels and first differences of the individual series, instead of basing the unit root tests on deviations from the estimated factors. Asymptotic results generated are for both the individual cross-sectionally augmented Dickey Fuller (CADF) statistics and for their simple averages (CIPS). 
$\operatorname{CIPS}(N, T)=N^{-1} \sum_{i=1}^{N} t_{i}(N, T)=\frac{\sum_{i=1}^{N} C A D F_{i}}{N}$

(9)

Where $t_{i}(N, T)=i$-th cross-section CADF statistic and $C A D F_{i}=t_{i}(N, T)=$

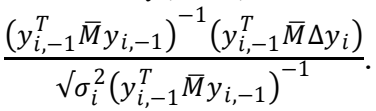

\subsubsection{Panel cointegration tests with cross-sectional dependence and} heterogeneous slopes

To test for long-run relationship between the variables, we adopt the Durbin-Hausman cointegration tests of Westerlund (2008). The Durbin-Hausman tests are valid even when cross-sectional dependence and slope heterogeneity are present in the data series. Another advantage of the tests is that they are still able to produce valid estimates even when the variables are integrated of a mixed order $(\mathrm{I}(0)$ and $\mathrm{I}(1))$; the only condition required being that the dependent variable is non-stationary. The Durbin-Hausman tests are expressed as:

$$
D H_{p}=\hat{S}_{n}(\tilde{\varphi}-\hat{\varphi})^{2} \sum_{i=1}^{n} \sum_{t=2}^{T} \hat{e}_{i t-1}^{2} \text { and } D H_{g}=\hat{S}_{i}\left(\tilde{\varphi}_{i}-\hat{\varphi}_{i}\right)^{2} \sum_{i=1}^{n} \sum_{t=2}^{T} \hat{e}_{i t-1}^{2}
$$

Where: $D H_{p}$ is the panel statistic and $D H_{g}$ is the group mean statistic. Their null hypothesis of no cointegration $\left[H_{0}: \varphi_{i}=1\right.$, for all $\left.\mathrm{I}=1\right]$ is tested against the alternative of cointegration in all $\mathrm{n}$ units for $D H_{p}\left[H_{i}^{p}: \varphi_{i}=\varphi\right.$, and $\left.\varphi<1\right]$ and against the alternative of cointegration in some of the cross sectional units for $D H_{g}\left[H_{i}^{p}: \varphi<1\right.$, for at least some $i]$.

\subsubsection{Long run estimation technique}

When panel-data series display cross-sectional dependence, slope heterogeneity and variable nonstationarity, specified econometric models are best estimated using the common correlated effects mean group (CCEMG) estimator (Pesaran, 2006), and the augmented mean group (AMG) estimator (Eberhardt and Teal, 2010).

By adding the cross-section averages of the dependent and independent variables as additional regressors when applying OLS to each unit, the common correlated effects mean group (CCEMG) estimator allows for cross-sectional dependence and time-variant unobservables with heterogeneous impact across panel members (Pesaran, 2006). Represented by the cross-sectional averages, the unobserved common factors can be any fixed number. With satisfactory small sample properties and robust estimator of shortrun dynamics, the CCEMG estimator is also very robust to structural breaks, nonstationary and noncointegrated common factors, and certain serial correlation (Kapetanios et al., 2011). The CCE estimator for the $i$-th country's slope coefficient is given as:

$\hat{\beta}_{C C E, i}=\left(E_{i}^{\prime} \bar{M} E_{i}\right)^{-1} E_{i}^{\prime} \bar{M} Y_{i}$

where $\bar{M}=I_{T}-\bar{H}\left(\bar{H}^{\prime} \bar{H}\right)^{-1} \bar{H}, \bar{H}=(\tau, \bar{Z}), \tau=(1, \ldots, 1)^{\prime}$ and $\bar{Z}$ represents a $T \times 2$ matrix of observations on $\bar{Z}_{t}, t=1, \ldots, T$.

The CCEMG estimator is generated as the simple average of the individual CCE estimators 
$\hat{\beta}_{M G}=\frac{1}{N} \sum_{i=1}^{N} \hat{\beta}_{C C E, i}$

The augmented mean group (AMG) approach alternatively estimates a pooled model augmented with year dummies by first-order difference OLS. Coefficients on the year dummies are obtained to generate a new variable, which represents the common dynamic process. The variable is then included as an additional regressor for each groupspecific regression model apart from an intercept to capture time-invariant fixed effects. The AMG exhibits similarly satisfactory performance as a CCEMG estimator in dealing with nonstationary variables and multifactor error terms, especially the cross-sectional dependence (Eberhardt and Bond, 2009; Bond and Eberhardt, 2013). The AMG relies on the following two-stage procedure:

Stage 1: $\Delta y_{i t}=\beta_{i} \Delta X_{i t}+\sum_{t=2}^{T} c_{t} \Delta D_{t}+e_{i t} \rightarrow \hat{c}_{t} \equiv \hat{v}_{t}$

Stage 2:

$$
y_{i t}=\delta_{i}+\beta_{i} X_{i t}+d_{i} \hat{v}_{t}+e_{i t}, \quad \hat{\beta}_{A M G}=N^{-1} \sum_{i} \hat{\beta}_{i}
$$

In the first stage, a standard FD-OLS regression with $T-1$ year dummies $\left(D_{t}\right)$ in first differences is estimated, and the year dummy coefficients $\left(\hat{v}_{t}\right)$ which represent the estimated cross-country averages of the evolution of unobservables over time (common dynamic process) are obtained. In the second stage, $\hat{v}_{t}$ is included in each of the $N$ standard country regressions along with a linear trend term which captures omitted idiosyncratic processes evolving over time. The estimates are then averaged across countries.

\section{Empirical Results}

As the first step in the analysis, we tested for cross-sectional dependence and crosscountry heterogeneity. Table 1 reports the results of the following cross-sectional dependence tests; Breusch-Pagan (1980) LM test, Pesaran (2004) Scaled LM test, Pesaran (2004) CD test and Pesaran et al. (2008) Bias-adjusted LM test. Test statistics produced by these four tests overwhelmingly reject the null hypothesis of no cross-sectional dependence at $(p<0.01)$ significance level or better. Furthermore, the null hypothesis of slope homogeneity is also rejected in our data series at $(p<0.05)$ significance level or better in all the variables except indexes for financial institution access and efficiency.

Table 1. Cross-sectional dependence and cross-country heterogeneity test results

\begin{tabular}{|c|c|c|c|c|c|c|c|}
\hline & $\begin{array}{l}\text { LM } \\
\text { (Breusch, }\end{array}$ & Pagan & $\begin{array}{l}\text { CDlm } \\
\text { (Pesaran }\end{array}$ & $\begin{array}{l}\text { CD } \\
\text { (Pesaran }\end{array}$ & $\begin{array}{l}\text { LMadj } \\
\text { (PUY, }\end{array}$ & $\widehat{\Delta}$ & $\widehat{\Delta}_{a d j}$ \\
\hline FII & $\begin{array}{l}1089.168^{* * *} \\
(0.000)\end{array}$ & & $\begin{array}{l}12.936^{* * *} \\
(0.000)\end{array}$ & $\begin{array}{l}0.958 \\
(0.169)\end{array}$ & $\begin{array}{l}6.660^{* * *} \\
(0.000)\end{array}$ & $\begin{array}{l}3.282^{* * *} \\
(0.001)\end{array}$ & $\begin{array}{l}3.499^{* * *} \\
(0.000)\end{array}$ \\
\hline FIA & $869.682^{* * *}$ & & $6.752^{* * *}$ & $-1.859^{* * *}$ & $8.872^{* * *}$ & $\begin{array}{l}1.159 \\
(0123)\end{array}$ & $\begin{array}{l}1.236 \\
(0.08)\end{array}$ \\
\hline FID & $\begin{array}{l}889.714^{* * *} \\
(0.000)\end{array}$ & & $7.317^{* * * *}$ & -0.933 & $7.544^{* * *}$ & $5.505^{* * *}$ & $5.868^{* * *}$ \\
\hline FIE & $\begin{array}{l}926.094^{* * *} \\
(0.000)\end{array}$ & & $\begin{array}{l}8.342^{* * *} \\
(0.000)\end{array}$ & $\begin{array}{l}-0.820 \\
(0.206)\end{array}$ & $\begin{array}{l}-1.923^{*} \\
(0.073)\end{array}$ & $\begin{array}{l}1.176 \\
(0.120)\end{array}$ & $\begin{array}{l}1.254 \\
(0.105)\end{array}$ \\
\hline EGI & $\begin{array}{l}1463.790^{* * *} \\
(0.000)\end{array}$ & & $\begin{array}{l}23.489^{* * *} \\
(0.000)\end{array}$ & $\begin{array}{l}1.189 \\
(0.117)\end{array}$ & $\begin{array}{l}2.355^{* * *} \\
(0.009)\end{array}$ & $\begin{array}{l}4.531^{* * *} \\
(0.000)\end{array}$ & $\begin{array}{l}4.830^{* * *} \\
(0.000)\end{array}$ \\
\hline PGI & $\begin{array}{l}896.244^{* * *} \\
(0.000)\end{array}$ & & $\begin{array}{l}7.501^{* * * *} \\
(0.000)\end{array}$ & $\begin{array}{l}-0.439 \\
(0.330)\end{array}$ & $\begin{array}{l}2.461^{* * *} \\
(0.007)\end{array}$ & $19.967^{* *}$ & $21.285^{* *}$ \\
\hline SGI & $\begin{array}{l}1065.117^{* * *} \\
(0.000)\end{array}$ & & $\begin{array}{l}12.258^{* * *} \\
(0.000)\end{array}$ & $\begin{array}{l}2.770^{* * *} \\
(0.003)\end{array}$ & $\begin{array}{l}1.947^{* *} \\
(0.026)\end{array}$ & $\begin{array}{l}6.226^{* * *} \\
(0.000)\end{array}$ & $\begin{array}{l}6.637^{* * *} \\
(0.000)\end{array}$ \\
\hline
\end{tabular}




\begin{tabular}{lllllll} 
OGI & $1079.869^{* * *}$ & $12.674^{* * *}$ & -0.348 & $8.746^{* *}$ & $5.439^{* * *}$ & $5.798^{* * *}$ \\
& $(0.000)$ & $(0.000)$ & $(0.364)$ & $(0.000)$ & $(0.000)$ & $(0.000)$ \\
GDPP & $1217.227^{* * *}$ & $16.543^{* * *}$ & $2.526^{* * *}$ & $7.115^{* * *}$ & $8.477^{* * *}$ & $9.036^{* * *}$ \\
C & $(0.000)$ & $(0.000)$ & $(0.006)$ & $(0.000)$ & $(0.000)$ & $(0.000)$ \\
IQ & $1267.755^{* * *}$ & $17.967^{* * *}$ & -1.282 & $2.114^{* *}$ & $5.517^{* * *}$ & $5.882^{* * *}$ \\
& $(0.000)$ & $(0.000)$ & $(0.100)$ & $(0.000)$ & $(0.000)$ & $(0.000)$ \\
TO & $941.681^{* * *}$ & $8.781^{* * *}$ & 0.687 & $6.398^{* * *}$ & $2.116^{* *}$ & $2.256^{* *}$ \\
& $(0.000)$ & $(0.000)$ & $(0.246)$ & $(0.000)$ & $(0.017)$ & $(0.012)$ \\
FO & $995.670^{* * *}$ & $10.302^{* * *}$ & -0.869 & $2.939^{* * *}$ & $10.155^{* *}$ & $10.826^{* *}$ \\
& $(0.000)$ & $(0.000)$ & $(0.192)$ & $(0.000)$ & $*$ & $*$ \\
\hline
\end{tabular}

After confirming the presence of cross-sectional dependency and slope heterogeneity, we proceeded to conducting panel unit root testing that is robust to these issues-the Pesaran (2007) CIPS test. The test results are reported in table 2. The test statistics presented are for the variables in levels and in their first differences with trend and intercept. When the variables are tested for unit root in their level form, there is not enough evidence to reject the null hypothesis of no unit root in all cases. After taking their first differences however, the test rejects the null hypothesis at $(p<0.10)$ or better in all cases. These findings lead to the conclusion all the variables are nonstationary and integrated of order I (0).

Table 2. Results from CIPS unit root tests with intercept and trend

\begin{tabular}{lll}
\hline & Level & Firs Differences \\
\hline FII & -2.626 & $-4.812^{* * *}$ \\
FIA & -1.597 & $-4.229^{* * *}$ \\
FID & -2.373 & $-4.490^{* * *}$ \\
FIE & -2.924 & $-5.199^{* * *}$ \\
EGI & -2.007 & $-4.299^{* * *}$ \\
PGI & -2.697 & $-4.902^{* * *}$ \\
SGI & -2.647 & $-5.000^{* * *}$ \\
OGI & -2.745 & $-4.840^{* * *}$ \\
GDPPC & -1.727 & $-3.174^{* * *}$ \\
IQ & -2.437 & $-3.737^{* * *}$ \\
TO & -2.029 & $-4.549^{* * *}$ \\
FO & -0.143 & $-2.68^{*}$ \\
\hline
\end{tabular}

Results from the Durbin-Hausman cointegration tests which help us deal with the challenges posed by cross-sectional dependence and slope heterogeneity are reported in table 3. On one hand, the significant $\mathrm{DH}_{\mathrm{p}}$ and $\mathrm{DH}_{\mathrm{g}}$ estimates reported for models 1 and 3 lead to our rejection of the null of no cointegration at $(p<0.01)$ in both cases. We thus reach the conclusion that cointegration exists in all the panel cross-sections. On the other hand, the significant $\mathrm{DH}_{\mathrm{g}}$ estimates reported for models 2 and 4 cause us to reject the null of no cointegration at $(p<0.10)$ in both cases. This indicates that cointegration exists in at least some of the panel cross-sections.

Table 3. Westerlund (2008) panel cointegration test results.

\begin{tabular}{lll}
\hline Models & DH_p & DH_g \\
\hline M1 & $2.871^{* * *}(0.002)$ & $-3.034^{* * *}(0.001)$ \\
M2 & $1.678(0.953)$ & $-1.431^{*}(0.076)$ \\
M3 & $-3.562^{* * *}(0.000)$ & $-2.852^{* * *}(0.002)$ \\
M4 & $3.388(0.995)$ & $-1.412^{*}(0.079)$ \\
\hline
\end{tabular}


Given the evidence of panel cointegration, the long-run relations of the models are further estimated through the CCEMG and AMG estimation procedures. Tables 4-7 report the estimation results from the CCEMG and AMG estimators for the overall financial institution development index and its sub-indices (financial institution access, depth and efficiency respectively). The main results, using overall financial institution development as dependent variable (M1), are reported in table 4. Both CCEMG and AMG estimates for the effects of globalization are positive and statistically significant, suggesting that globalization stimulates financial institutions development. The coefficient estimates range between $0.143-0.223 \%$ for economic globalization, between $0.367-0.801 \%$ for political globalization, between $0.079-0.149 \%$ for social globalization and between $0.282-0.412 \%$ for overall globalization. Two important inferences can be made from these findings. The first is that all aspects of globalization are crucial to the development of financial institutions. The other is that the range of point estimates for political globalization is substantially larger than the range for the other dimensions of globalization, suggesting that of all the dimensions of globalization, political globalization is the most important driver of financial institutions development.

With respect to the control variables, the CCEMG and AMG coefficients for gross domestic product per-capita are positive and significant in all the 8 estimations reported in table 4, with point estimates ranging between $0.151-0.528 \%$. This finding confirms that income levels play an important role in the development of financial institutions. All the coefficients for trade openness obtained from the CCEMG and AMG estimations in table 7 are positive and significant with point estimates ranging between $0.005-0.236 \%$. This establishes that the opening up of the goods market as a macroeconomic policy is an important determinant of financial institutions development. All the coefficients for institutional quality are positive and significant, with point estimates ranging between $0.006-0.031 \%$. We thus affirm that the quality of institutions positively impacts the development of financial institutions. We however estimate insignificant effects of financial openness on financial institutions development in all cases, and find no significant impact of financial openness on the development of financial institutions.

As a form of robustness check, we further split the financial institutions development index into its main sub-indices (financial institutions access, depth and efficiency). We then re-estimate the long-run effects of globalization (economic, political, social and overall) on each of the sub-indices. As reported in table 5, all the measures of globalization are significantly positively associated with financial institutions access. In table 6 , the results similarly show that all the measures of globalization exert positive and significant influence over financial depth. In both tables 5 and 6, political globalization again turns out to be the most powerful driver of financial institutions development. In table 7 however, only economic globalization has a significant impact on the efficiency of financial institutions. Concerning the control variables, effects similar to those recorded in the main estimation reported in table 4 are again detected. In tables 5-7, gross domestic product per-capita, trade openness and institutional quality are significantly positively related to financial access, depth and efficiency respectively while the coefficients for financial openness turn out as mostly insignificant. 
Table 4. Estimates for the Long-run Relationship (Dependent Variable: FII)

\begin{tabular}{lllllllll}
\hline & \multicolumn{2}{l}{ CCEMG } & \multicolumn{7}{c}{ AMG } \\
\hline Regressors & $\mathrm{A}$ & $\mathrm{B}$ & $\mathrm{C}$ & $\mathrm{D}$ & $\mathrm{A}$ & $\mathrm{B}$ & $\mathrm{C}$ & $\mathrm{D}$ \\
\hline EGI & $0.143^{*}$ & & & & $0.223^{* * *}$ & & & \\
& $(0.073)$ & & & & $(0.008)$ & & & \\
PGI & & $0.367^{* * *}$ & & & & $0.801^{*}$ & & \\
& & $(0.000)$ & & & & $(0.098)$ & & \\
SGI & & & $0.141^{* * *}$ & & & & $0.079^{*}$ & \\
& & & $(0.000)$ & & & & $(0.072)$ & \\
OGI & & & & $0.412^{* *}$ & & & & $0.282^{*}$ \\
& & & & $(0.025)$ & & & & $(0.056)$ \\
GDPPC & $0.219^{* * *}$ & $0.208^{* * *}$ & $0.151^{* * *}$ & $0.528^{* * *}$ & $0.436^{* * *}$ & $0.317^{* *}$ & $0.479^{* * *}$ & $0.426^{* * *}$ \\
& $(0.000)$ & $(0.000)$ & $(0.000)$ & $(0.000)$ & $(0.000)$ & $(0.007)$ & $(0.000)$ & $(0.000)$ \\
TO & $0.236^{*}$ & $0.091^{* * *}$ & $0.032^{*}$ & $0.005^{* * *}$ & $0.139^{* * *}$ & $0.088^{* *}$ & $0.081^{* *}$ & $0.095^{* *}$ \\
& $(0.057)$ & $(0.000)$ & $(0.073)$ & $(0.004)$ & $(0.003)$ & $(0.040)$ & $(0.031)$ & $(0.037)$ \\
FO & 0.035 & -0.009 & 0.006 & 0.002 & 0.009 & 0.002 & 0.009 & 0.008 \\
& $(0.211)$ & $(0.336)$ & $(0.696)$ & $(0.900)$ & $(0.526)$ & $(0.893)$ & $(0.502)$ & $(570)$ \\
IQ & $0.029^{* * *}$ & $0.031^{* * *}$ & $0.025^{* * *}$ & $0.029^{* * *}$ & $0.006^{* * *}$ & $0.007^{* * *}$ & $0.010^{*}$ & $0.029^{* * *}$ \\
& $(0.000)$ & $(0.000)$ & $(0.000)$ & $(0.000)$ & $(0.000)$ & $(0.000)$ & $(0.083)$ & $(0.000)$ \\
\hline
\end{tabular}

Table 5. Estimates for the Long-run Relationship (Dependent Variable: FIA)

\begin{tabular}{lllllllll}
\hline & CCEMG & \multicolumn{7}{c}{ AMG } \\
\hline Regressors & A & B & C & D & A & B & C & D \\
\hline EGI & $0.091^{*}$ & & & & $0.052^{* *}$ & & & \\
PGI & $(0.097)$ & & & & $(0.016)$ & & & \\
& & $0.214^{* * *}$ & & & & $0.168^{*}$ & & \\
SGI & & $(0.000)$ & & & & $(0.075)$ & & \\
& & & $0.137^{* * *}$ & & & & $0.102^{* *}$ & \\
OGI & & & $(0.001)$ & & & & $(0.029)$ & \\
& & & & $0.152^{* * *}$ & & & & $0.124^{* * *}$ \\
GDPPC & $0.138^{* * *}$ & $0.133^{* * *}$ & $0.122^{* * *}$ & $0.092^{* * *}$ & $0.207^{* * *}$ & $0.225^{* * *}$ & $0.215^{* * *}$ & $0.297^{* * *}$ \\
& $(0.000)$ & $(0.000)$ & $(0.000)$ & $(0.000)$ & $(0.000)$ & $(0.000)$ & $(0.000)$ & $(0.000)$ \\
TO & $0.044^{* *}$ & $0.020^{* *}$ & $0.041^{* * *}$ & $0.038^{* * *}$ & $0.044^{* *}$ & $0.007^{* *}$ & $0.004^{*}$ & $0.112^{* *}$ \\
& $(0.023)$ & $(0.031)$ & $(0.008)$ & $(0.000)$ & $(0.018)$ & $(0.022)$ & $(0.081)$ & $(0.011)$ \\
FO & 0.012 & 0.004 & 0.002 & $0.015^{* *}$ & 0.011 & 0.005 & 0002 & 0.005 \\
& $(0.116)$ & $(0.448)$ & $(0.660)$ & $(0.018)$ & $(0.989)$ & $(0.594)$ & $(0.602)$ & $(0.400)$ \\
IQ & $0.009^{* * *}$ & $0.009^{* * *}$ & $0.007^{* * *}$ & $0.009^{* * *}$ & $0.003^{* * *}$ & $0.006^{* * *}$ & $0.002^{* * *}$ & $0.006^{* * *}$ \\
& $(0.001)$ & $(0.000)$ & $(0.008)$ & $(0.001)$ & $(0.000)$ & $(0.000)$ & $(0.000)$ & $(0.000)$ \\
\hline
\end{tabular}

Table 6. Estimates for the Long-run Relationship (Dependent Variable: FID)

\begin{tabular}{|c|c|c|c|c|c|c|c|c|}
\hline & CCEMC & & & & AMG & & & \\
\hline Regressors & $\mathrm{A}$ & B & $\mathrm{C}$ & $\mathrm{D}$ & A & B & $\mathrm{C}$ & $\mathrm{D}$ \\
\hline EGI & $\begin{array}{l}0.321^{* *} \\
(0.036)\end{array}$ & & & & $\begin{array}{l}0.188^{* *} \\
(0.020)\end{array}$ & & & \\
\hline PGI & & $\begin{array}{l}0.895^{* * *} \\
(0.000)\end{array}$ & & & & $\begin{array}{l}0.741^{\text {*** }} \\
(0.000)\end{array}$ & & \\
\hline SGI & & & $\begin{array}{l}0.690^{* * *} \\
(0.000)\end{array}$ & & & & $\begin{array}{l}0.261^{* *} \\
(0.037)\end{array}$ & \\
\hline OGI & & & & $0.673^{*}$ & & & & $0.404^{*}$ \\
\hline
\end{tabular}




\begin{tabular}{lllllllll} 
& & & & $(0.085)$ & & & $(0.088)$ \\
GDPPC & $0.174^{* * *}$ & $0.143^{* * *}$ & $0.075^{* *}$ & $0.272^{* * *}$ & $0.599^{* * *}$ & $0.680^{* * *}$ & $0.433^{* *}$ & $0.616^{* * *}$ \\
TO & $(0.000)$ & $(0.000)$ & $(0.043)$ & $(0.000)$ & $(0.000)$ & $(0.000)$ & $(0.020)$ & $(0.000)$ \\
& $0.234^{*}$ & $0.225^{* * *}$ & 0.057 & $0.341^{* *}$ & $0.027^{*}$ & $0.057^{*}$ & $0.054^{*}$ & $0.027^{*}$ \\
FO & $(0.087)$ & $(0.000)$ & $(0.537)$ & $(0.048)$ & $(0.077)$ & $(0.082)$ & $(0.088)$ & $(0.077)$ \\
& 0.032 & 0.023 & $0.032^{*}$ & 0.006 & 0.010 & 0.007 & 0.009 & 0.007 \\
IQ & $(0.280)$ & $(0.180)$ & $(0.067)$ & $(0.832)$ & $(0.632)$ & $(0.641)$ & $(0.610)$ & $(0.680)$ \\
& $0.081^{* * *}$ & $0.083^{* * *}$ & $0.073^{* * *}$ & $0.028^{*}$ & $0.017^{* * *}$ & $0.021^{* *}$ & $0.022^{* *}$ & $0.013^{* * *}$ \\
& $(0.000)$ & $(0.000)$ & $(0.000)$ & $(0.064)$ & $(0.000)$ & $0.018)$ & $(0.039)$ & $(0.005)$ \\
\hline
\end{tabular}

Table 7. Estimates for the Long-run Relationship (Dependent Variable: FIE)

\begin{tabular}{lllllllll}
\hline \multicolumn{3}{c}{ CCEMG } & \multicolumn{7}{c}{ AMG } \\
\hline Regressors & $\mathrm{A}$ & $\mathrm{B}$ & $\mathrm{C}$ & $\mathrm{D}$ & $\mathrm{A}$ & $\mathrm{B}$ & $\mathrm{C}$ & $\mathrm{D}$ \\
\hline EGI & $0.410^{* *}$ & & & & $0.397^{* *}$ & & & \\
& $(0.021)$ & & & & $(0.022)$ & & & \\
PGI & & 0.488 & & & & 0.441 & & \\
SGI & & $(0.187)$ & & & & $(0.539)$ & & \\
& & & 0.017 & & & & 0.196 & \\
OGI & & & $(0.698)$ & & & & $(0.358)$ & \\
& & & & -0.047 & & & & 0.509 \\
GDPPC & $0.048^{* * *}$ & $0.050^{* * *}$ & $0.045^{* * *}$ & $(0.525)$ & & & & $(0.101)$ \\
& $(0.000)$ & $(0.000)$ & $(0.001)$ & $(0.000)$ & $(0.000)$ & $(0.000)$ & $(0.070)$ & $(0.001)$ \\
TO & $0.073^{* * *}$ & $0.066^{* * *}$ & $0.071^{* * *}$ & $0.075^{* * *}$ & $0.075^{* * *}$ & $0.082^{* * *}$ & 0.072 & $0.067^{* *}$ \\
& $(0.000)$ & $(0.000)$ & $(0.000)$ & $(0.000)$ & $(0.000)$ & $(0.004)$ & $(0.468)$ & $(0.043)$ \\
FO & 0.002 & 0.004 & 0.001 & 0.001 & 0.002 & 0.005 & 0.014 & 0.006 \\
& $(0.119)$ & $(0.809)$ & $(0.983)$ & $(0.896)$ & $(0.281)$ & $(0.517)$ & $(0.287)$ & $(0.605)$ \\
IQ & $0.007^{* *}$ & $0.014^{*}$ & $0.013^{* *}$ & $0.005^{* *}$ & $0.011^{*}$ & $0.013^{* *}$ & $0.020^{* *}$ & $0.011^{*}$ \\
& $(0.028)$ & $(0.062)$ & $(0.021)$ & $(0.031)$ & $(0.090)$ & $(0.021)$ & $(0.022)$ & $(0.091)$ \\
\hline
\end{tabular}

\section{Conclusion}

Financial development has been well documented in literature as an important driver of economic growth. Due to its significant influence on economic growth, several researchers have investigated the determinants of financial development. In recent times, arguments have emerged concerning the role of globalization in financial sector development. This study examines the impact of globalization (economic, political, social and overall) on financial institutions development in 36 countries from 1996 to 2016. Panel unit root tests with cross-sectional dependence and heterogeneous slopes, DurbinHausman panel cointegration tests and CCEMG and AMG estimation procedures were applied. Empirical evidence from our analysis illustrates that there is a long-run relationship between globalization and financial institutions development, and also between globalization and the sub-indices of financial institutions development (financial access, depth and efficiency). Empirical evidence obtained also shows that all the dimensions of globalization exert positive and statistically significant influence over financial institutions index and two of its sub-indices (access and depth). Only economic globalization has a significant effect on financial institutions efficiency. Overall, our findings confirm Mishkin's (2009) hypothesis that globalization plays a key role in 
promoting institutional reforms that encourage financial development. Furthermore, based on our empirical findings, there is no evidence to suggest that a simultaneous opening of both trade and capital is necessary to achieve development in financial institutions. This is contradictory to the findings of Rajan and Zingales (2003) who argues that twin openings leads to financial development and Baltagi et al. (2009) who gives limited support to this finding.

Another important empirical finding of ours is that of all the dimensions of globalization, political globalization is the most important driver of financial institutions development. Political globalization which is more of a movement toward multilateralism characterized by collaboration rather than unilateralism is a phenomenon that has led to countries around the world becoming increasingly interactive, not just in terms of politics but also in terms of economic and cultural integration. Political globalization often precedes economic and social globalization. Its effects are mainly reflected through occurrences such as democratization across the world, creation of the global civil society and the growing prevalence of intergovernmental agencies like the International Monetary Fund, World Bank, World Trade Organization and United Nations. These characteristics of political globalization are undoubtedly very important for development of financial institutions across the world.

\section{References}

Acemoglu, D., Johnson, S., \& Robinson, J. A. (2001). The colonial origins of comparative development: An empirical investigation. American economic review, 91(5), 1369-1401.

Al-Marhubi, F. (2004). The Determinants of Governance: A Cross-Country Analysis. Contemporary Economic Policy, 22(3), 394-406.

Ang, J. B. (2008). A survey of recent developments in the literature of finance and growth. Journal of economic Surveys, 22(3), 536-576.

Baltagi, B. H., Demetriades, P. O., \& Law, S. H. (2009). Financial development and openness: Evidence from panel data. Journal of development economics, 89(2), 285-296.

Beck, T. (2012). The role of finance in economic development-benefits, risks, and politics. Oxford Handbook of Capitalism, 161-203.

Beck, T., Demirgüç-Kunt, A., \& Levine, R. (2003). Law, endowments, and finance. Journal of financial Economics, 70(2), 137-181.

Bjørnskov, C. (2006). The multiple facets of social capital. European journal of political economy, 22(1), 22-40.

Bond, S., \& Eberhardt, M. (2013). Accounting for unobserved heterogeneity in panel time series models. Nuffield College, University of Oxford, mimeo.

Breusch, T. S. \& Pagan, A. R. (1980). The Lagrange multiplier test and its applications to model specification in econometrics. The Review of Economic Studies, 47(1), 239-253.

Do, Q. T. \& Levchenko. A. A. (2004). Trade and Financial Development. World Bank Working Paper No. 3347. Washington, DC: World Bank.

Dreher, A. (2006). Does globalization affect growth? Evidence from a new index of globalization. Applied Economics, 38(10), 1091-1110.

Easterly, W. (2002). The cartel of good intentions: the problem of bureaucracy in foreign aid. The Journal of Policy Reform, 5(4), 223-250.

Eberhardt, M., \& Bond, S. (2009). Cross-section dependence in nonstationary panel models: a novel estimator.

Eberhardt, M., \& Teal, F. (2010). Productivity Analysis in Global Manufacturing Production.

Gygli, S., Haelg, F., \& Sturm, J. E. (2018). The KOF Globalisation Index-Revisited. KOF Working Papers, 439.

Huang, Y. (2011). Determinants of financial development. Palgrave Macmillan. 
Im, K. S., Pesaran, M. H., \& Shin, Y. (2003). Testing for unit roots in heterogeneous panels. Journal of econometrics, 115(1), 53-74.

Kapetanios, G., Pesaran, M. H., \& Yamagata, T. (2011). Panels with non-stationary multifactor error structures. Journal of Econometrics, 160(2), 326-348.

Langbein, L., \& Knack, S. (2010). The worldwide governance indicators: Six, one, or none? The Journal of Development Studies, 46(2), 350-370.

Law, S. H., \& Azman-Saini, W. N. W. (2012). Institutional quality, governance, and financial development. Economics of Governance, 13(3), 217-236.

Le, T. H., Kim, J., \& Lee, M. (2016). Institutional quality, trade openness, and financial sector development in Asia: An empirical investigation. Emerging Markets Finance and Trade, 52(5), 1047-1059.

Levine, R. (1999). Financial development and economic growth: views and agenda. Journal of Economic Literature, Vol XXXV, 688-726.

Levine, R. (1999). Financial development and economic growth: views and agenda. The World Bank.

Levine, R. (2003). More on finance and growth: more finance, more growth? Review-Federal Reserve Bank of Saint Louis, 85(4), 31-46.

Levine, R. (2005). Finance and growth: theory and evidence. Handbook of economic growth, 1, 865-934.

Mayer, C., \& Sussman, O. (2001). The assessment: finance, law, and growth. Oxford Review of Economic Policy, 17(4), 457-466.

McKinnon, R. I. (2010). Money and capital in economic development. Brookings Institution Press.

Mishkin, F. S. (2009). Globalization and financial development. Journal of development Economics, 89(2), 164-169.

Paşali, S. S. (2013). Where is the cheese? Synthesizing a giant literature on causes and consequences of financial sector development. The World Bank.

Pesaran, M. H. (2004). General diagnostic tests for cross section dependence in panels.Cambridge Working Papers in Economics No. 435, University of Cambridge, and CESifo Working Paper Series No. 1229.

Pesaran, M. H. (2006). Estimation and inference in large heterogeneous panels with a multifactor error structure. Econometrica, 74(4), 967-1012.

Pesaran, M. H. (2007). A simple panel unit root test in the presence of cross-section dependence. Journal of applied econometrics, 22(2), 265-312.

Pesaran, M. H., \& Yamagata, T. (2008). Testing slope homogeneity in large panels. Journal of Econometrics, 142(1), 50-93.

Pesaran, M. H., Ullah, A., \& Yamagata, T. (2008). A bias-adjusted LM test of error cross-section independence. The Econometrics Journal, 11(1), 105-127.

Porta, R. L., Lopez-de-Silanes, F., Shleifer, A., \& Vishny, R. W. (1998). Law and finance. Journal of political economy, 106(6), 1113-1155.

Porta, R. L., Lopez-de-Silanes, F., Shleifer, A., \& Vishny, R. W. (1997). Legal determinants of external finance. The journal of finance, 52(3), 1131-1150.

Prasad, E., Rogoff, K., Wei, S. J., \& Kose, M. A. (2005). Effects of financial globalization on developing countries: some empirical evidence. In India's and China's recent experience with reform and growth (pp. 201-228). Palgrave Macmillan, London.

Rajan, R. G., \& Zingales, L. (2003). The great reversals: the politics of financial development in the twentieth century. Journal of financial economics, 69(1), 5-50.

Schmukler, S. L., \& Abraham, F. (2017). Financial Globalization.

Shaw, E. S. (1973). Financial Deepening in Economic Development, New York: Oxford Univ. Press.

Swamy, P. A. (1970). Efficient inference in a random coefficient regression model. Econometrica: Journal of the Econometric Society, 311-323.

Tovar García, E. D. (2012). Financial globalization and financial development in transition countries. Economía: teoría y práctica, (36), 155-178.

Westerlund, J. (2008). Panel cointegration tests of the Fisher effect. Journal of Applied Econometrics, 23(2), 193233. 


\section{Appendix: List of Countries}

Austria, Bangladesh, Belgium, Botswana, Cyprus, Denmark, Egypt, France, Germany, India, Indonesia, Ireland, Israel, Italy, Kenya, Korea, Kuwait, Malta, Mauritius, Morocco, Netherlands, Nigeria, Norway, Pakistan, Philippines, Poland, Portugal, Romania, Sweden, Switzerland, Tanzania, Thailand, Tunisia, Ukraine, United States. 